\title{
PENERAPAN MODEL PEMBELAJARAN PENINGKATKAN KAPASITAS BERPIKIR KRITIS PADA MATA KULIAH MEMBACA
}

\author{
Oleh: \\ I l h a m \\ Dosen Pendidikan Bahasa Inggris Universitas Muhammadiyah Mataram
}

\begin{abstract}
Abstrak: Artikel ini membahas model pembelajaran yang meningkatkan kemampuan berpikir kritis siswa. Model ini berasumsi bahwa membaca adalah proses memahami ide penulis yang ada dalam tulisannya. Untuk memahami teks, pembaca harus memaksimalkan kapasitas berpikir kritis mereka. Model ini memberikan tantangan dan kesempatan kepada siswa untuk melatih dan mengembangkan kemampuannya dalam berpikir kritis. Pengembangan ketrampilan membaca kritis menuntut guru agar terampil dalam mengajar. Metode dan pendekatan yang digunakan dalam pembelajaran berpikir kritis harus mengantarkan siswa terampil dalam mengantarkan siswa stratefi berpikir kritis.
\end{abstract}

Kata Kunci: membaca kritis, berpikir kritis, kapasistas berpikir kritis

\section{PENDAHULUAN}

Berpikir kritis penting pada era milennium karena perubahan cepat dan pesat terjadi pada berbagai bidang seperti pendidikan, politik, ekonomi, ilmu pengetahuan, teknologi dan budaya. Hal ini memungkinkan semua pihak dapat memperoleh informasi dengan melimpah, cepat dan mudah. Kondisi seperti ini merupakan tantangan yang hanya dihadapi oleh orang-orang terdidik di masa depan yang mempunyai kemampuan mendapatkan, memilih dan mengolah informasi atau pengetahuan dengan efektif dan efesien. Agar orangorang terdidik dimasa depan mempunyai kemampuan diperlukan sistem pendidikan yang berorientasi berpikir kritis, kreatif, sistematis dan logis (Depdiknas, 2003 dalam Fachrurozzi, 2011). Gardner, (2001 pada Buranapatana, 2006) mengatakan bahwa pentingnya pada era informasi ini kemampuan untuk mengolah data dan menyatukan informasi. Kebutuhan memproses informasi membutuhkan kemampuan berpikir, analisa, serta evaluasi yang tinggi yang menjadi fokus pembelajaran.

Penguasaan berpikir kritis harus dipandang sebagai sesuatu yang urgen dan tidak bisa disepelekan. Penguasaan kemampuan berpikir kritis tidak cukup dijakdikan sebagai tujuan pendidikan semata, tetapi juga sebagai proses fundamental yang memungkinkan siswa untuk mengatasi ketidaktentuan masa mendatang (Cabera, 1992 dalam Fachrurozzi, 2011).

Pada konteks pembelajaran bahasa Inggris di Indonesia kebutuhan mengajarkan bahasa Inggris yang berkaitan dengan situasi terkini sangat disarankan (Alwasilah, 1998 dalam Emilia, 2005). Sehingga, itu merupakan kewajiban guru untuk membantu siswa meningkatkan kemampuan berpikir kritis ketika belajar bahasa Inggris. Tanpa latihan yang cukup berpikir kritis, siswa bahasa Inggris akan kehilangan kesempatan pada dunia kerja dan tidak mampu berpartisipasi pada komunitas internasional.

Pertanyaan berkaitan dengan bagaimana mengajarkan kemampuan berpikir pada bahasa Inggris telah menjadi fokus beberapa peneliti. Penelitian sebelumnya menunjukkan berbagai teknik disarankan. Sebagai contoh, Kabilan, (2000) menyarankan menggunakan pertanyaan berdasarkan teori Freire (1973); Zainudin dan Moore (2003) melakukan experiment menggunakan teknik dialog controversial terstruktur untuk meningkatkan kemampuan berpikir kritis pembelajar.

Beberapa hasil penelitian menunjukkan kemampuan berpikir siswa pada aspek membaca. Penelitian yang dilakukan oleh Emilia (2005) pada susunan berpikir kritis yaitu berpikir kritis, pengajaran berpikir kritis dan kemampuan membaca dan menulis kritis pada pengajaran menulis akademik menggunakan pendekatan genre-based bahwa siswa menyadari kemampuan berbahasa mereka meningkat untuk mendiskusikan membaca dan menulis kritis. Penelitian lain dilakukan oleh Liaw (2007) pada penggunaan pendekatan membaca dan menulis berbasis konten untuk meningkatkan kemampuan berpikir kritis dan berbahasa Inggris menunjukkan bahwa terjadi peningkatan yang signifikan pada kemampuan berbahasa serta kemampuan berpikir kritis pada materi yang dikuasai. Selanjutnya penelitian dilakukan oleh Kustini (2010) meneliti meningkatkan kemampuan berpikir kritis pada pengajaran membaca.Penelitian 
ini menemukan bahwa program pengajaran berhasil meningkatkan kemampuan berpikir kritis mahasiswa. Data dari observasi dan interview menunjukkan bahwa kemampuan berpikir kritis mahasiswa meningkat terlihat dari kemampuan menjelaskan konsep, criteria, skill pada materi membaca. Mahassiwa memnyadari pentingnya pengajar menyediakan suasana kelas yang nyaman dan bersahabat sebagai pondasi dan pembentuk kelas yang mampu menin gkatkan kemampuan berpikir kritis.

Sehubungan dengan pentingnya pengajaran berpikir kritis dan kemungkinan meningkatkan kapasistas berpikir kritis menggunakan teknis yang dijelaskan di atas, penelitian ini mencoba menggunkan berpikir kritis pada pengajaran membaca sebagai usaha untuk meningkatkan kemampuan berpikir kritis siswa dalam membaca text.

Konsepsi berpikir kritis berasal dari dua kata dasar dalam bahasa latin yakni "kritikos" yang berarti penilaian yang cerdas (discerning Judgement), bertanya, logis dan mampu dianalisa dan criterion yang berarti standard (Paul,2001; Chaffe, 2000, p.45) Chaffe mengungkapkan bahwa berpikir kritis yaitu dengan bertanya, melogiskan pikiran dan evaluasi pikiran sendiri dan pikiran orang lain.

Berpikir kritis adalah kemampuan menggunakan pikiran. Pemikir kritis menggunakan kualitas pemikiran tertentu (Paul, 2001). Mereka memiliki kemampuan menerapkan pikiran dengan tepat sesuai dengan kondisi dan tujuan dan sangat terbuka. Pemikir kritis mempunyai sikap skeptis (Mcpeck, 1981) dan berpikir terbuka (Ennis, 1989, Chaffe, 2000; Reichenbach, 2001; Lipman, 2003). Mereka menghargai pendapat, respek terhadap bukti, alasan, kejelasan dan ketepatan (Paul, 2001).

Menurut Halpen (1996 dalam Hoerudin, 2010) berpikir kritis adalah memberdayakan ketrampilan atau strategi kognitif dalam menentukan tujuan. Berpikir kritis juga merupakan kegiatan mengevaluasi, mempertimbangkan kesimpulan yang akan diambil manakala menentukan beberapa faktor pendukung untuk membuat keputusan. Pendapat senada dikemukan oleh Angelo (1995 dalam Hoerudin, 2010) berpikir kritis adalah mengaplikasikan rasional, kegiatan berpikir yang tinggi, yang meliputi kegiatan menganalisis, mensisntesis, mengenal permasalahan dan pemecahannya, menyimpulkan dan mengevaluasi.

Berpikir kritis merupakan salah satu proses berpikir tingkat tinggi yang dapat digunakan dalam system konseptual siswa. Menurut Ennis (1989) berpikir kritis adalah cara berpikir reflektif yang masuk akal berdasarkan nalar yang difokuskan untuk menentukan apa yang harus diyakini dan dilakukan.

\section{INDIKATOR DAN KOMPONEN BERPIKIR KRITIS}

Ennis (1985 dalam Haerodin, 2010) mengidentifikasi 12 indikator berpikir kritis. Indikator tersebut adalah sebagai berikut:

a. Memberikan penjelasan sederhana, yang berisi: memfokuskan pertanyaan, menganalisa pertanyaan, dan bertanya dan menjawab pertanyaan tentang suatu penjelasan atau pernyataan.

b. Membangun ketrampilan dasar, yang terdiri atas mempertimbangkan apakah sumber dapat dipercaya atau tidak dan mengamati dan mempertimbangkan suatu laporan hasil observasi.

c. Menyimpulkan, yang terdiri atas kegiatan mendeduksi atau mempertimbangkan hasil deduksi, meninduksi atau mempertimbangkan hasil indeksi, dan membuat dan menetukan nilai pertimbangan.

d. Memberikan penjelasan lanjut, yang terdiri atas mengidentifikasi istilah-istilah dan definisipertimbangan dan juga dimensi, dan mengidentifikasi asumsi.

e. Mengatur strategi dan teknik yang terdiri atas menetukan tindakan dan berinteraksi dengan orang lain.

Indikator-indikator tersebut dalam prakteknya dapat bersatu padu membentuk sebuah kegiatan atau terpisah-pisah hanya beberapa indikator saja.

Karakteristik tertentu dibutuhkan untuk pengembangan, pelatihan dan keberhasilan berpikir kritis, seperti kemampuan menghargai pendapat orang lain dan mempertimbangkan secara mendalam dan cermat problem yang dihadapi. Seperti penjelasan Norris dan Ennis (1989) untuk penerapan proses berpikir kritis secara efektif seseorang membutuhkan dua skill yakni aspek kognitif dan aspek afektif. Kemampuan kognitif termasuk mampu berinteraksi secara efektif dengan orang lain, menghasilkan informasi yang bisa dipercaya dan mampu memastikan kebenarannya dan untuk memberikan kejelasan. Sedangkan kemampuan afektif mencakup sikap, komitmen dan tendensi untuk melakukan (Norris dan Ennis, 1989).

\section{PEMBAHASAN}

\section{a. Pengajaran Berpikir Kritis}

Adanya ekpektasi yang tinggi pada pengajaran berpikir di sekolah akan menyiapkan siswa untuk hidup sukses dan berhasil di tempat kerja pada 
perubahan dunia yang sangat cepat. Pengajaran berpikir juga berpotensi untuk berkontribusi terhadap kehidupan sosial demokrasi. Ketika mempertimbangkan bagaimana membantu siswa menjadi pemikir kritis yang lebih baik, pendidik memiliki variasi pendekatan untuk dipilih, pendekatan tersebut berupa program pengajaran, pengajaran langsung untuk kemampuan tertentu sampai pengajaran tidak langsung yang menekankan kemampuan berpikir kritis.

Menurut Ennis (1992) dan Stenberg (1978) terdapat tiga pendekatan dalam pengajaran berpikir krtitis: pendekatan umum (general approach), infusion dan immersion dan pendekatan gabungan (mixed approach). Pendekatan umum mengajarkan siswa berpikir kritis menggunakan konteks non sekolah; dalam hal berpikir kritis secara umum dipisahkan. Sedangkan Infusi pada berpikir kritis yaitu metode pengajaran materi dimana kemampuan berpikir kritis diajarkan secara explisit dan siswa didorong untuk berpikir kritis pada materi tersebut. Pendekatan gabungan merupakan kombinasi dari pendekatan umum dan pendekatan infusi. Adanya pengajaran terpisah yang bertujuan mengajarkan prinsip berpikir kritis ketika siswa belajar materi tertentu. Sehingga, penelitian ini menggunakan metode ini karena diklaim sebagai metode yang terbaik (Stenberg, 1987). Stenberg mengatakan bahwa Infusi dan pemisahan (separation) memiliki kelebihan. Pada model gabungan (mix-method), kemampuan berpikir diajarkan sebagai pengajaran terpisah dalam satu kurikulum yang digunakan.

\section{b. Berpikir Kritis dalam Membaca}

Pengembangan kemampuan berpikir cenderung terjadi dalam lingkup pendidikan karena sekolah biasanya tempat pertama belajar informasi yang diperoleh. Kebanyakan informasi tersebut diperoleh dari bacaan, sehingga perkembangan proses berpikir secara logis dimulai dengan membaca, kemudian menulis, di sekolah menengah atau perguruan tinggi, siswa biasanya diajarkan jenis-jenis teks, esay, teks akademik, fiksi dan lain lain yang memberikan mereka kesempatan untuk menganalisa struktur dan isi dari teks yang berbeda. Memperhatikan budaya internasional sekarang, banyak informasi dibaca dalam bahasa Inggris di seluruh dunia sehingga diperlukan memasukkan berpikir kritis pada mata kuliah membaca.

Di dalam teks yang akan ajarkan berpikir kritis, seseorang harus mempertimbangkan dan mengenali aspek berikut yang disarankan oleh Stapleton (2001, dalam Alagozlu, 2006), untuk mengkritisi dan menanyakan ide atau pikiran yang ada dalam teks, dan ini menjadi focus penelitian ini:

1. Argumen: argumen adalah klaim yang didukung oleh beberapa alasan. Sebuah klaim terdiri atas pernyataan yang kebenarannya diperdebatkan, dan digunakan untuk menjawab masalah atau isu kontroversial. Klaim tanpa alasan kuat merupakan opini dan tidak bisa diklasifikasikan sebagai argumen. Klaim bisa berupa proposal, definisi dan evaluasi (Reihenbach, 2001; Diesler, 2001; Moore dan Parker, 1995; Chaffee, 2000).

2. Alasan: alasan adalah statemen yang digunakan untuk mendukung klaim dan biasanya untuk menjawab kenapa klaim harus dipercaya. Alasan menunjukkan hubungan langsung yang logis terhadap klaim sehingga bisa memperkuat argumen. Alasan tidak harus baru tetapi jika hanya berupa pengulangan tanpa elaborasi maka itu tidak mengindikasikan berpikir kritis (Reichenbach, 2001; Diesler, 2001; Moore dan Parker, 1995; Chaffee, 2000).

3. Bukti yakni pernyataan untuk memperkuat argumen. Dapat diartikan untuk mendukung kebenaran pendapat, khususnya dari penelitian observasi atau pengalaman. Bentuk bukti dapat berupa pengalalaman pribadi, hasil penelitian, statistik, pendapat ahli, perbandingan dan analogi, menunjukkan konsekuensi, fakta, penjelasan logis dan kata yang bermakna.

4. Kesimpulan: kesimpulan ialah pernyataan atau bagian pernyataan yang ditulis oleh penulis agar dipercaya oleh pembaca. Kepercayaan ini didapat dari argument, bukti dan pernyataan lain yang digunakan oleh penulis untuk menandai keyakinannya. Kesimpulan dibatasi dalam bentuk setuju, tidak setuju atau mengambil jalan tengah. (Diesler, 2001; Chaffee, 2000).

5. Eror (Falaccies) kesalahan dalam memberikan alasan. Diesler, (2001; Chaffee, 2000) mengatakan bahwa berpikir kritis ialah untuk mencari kesalahan yang logis. Hal ini terjadi ketika alasan tidak cukup mendukung klaim dari beberapa aspek.

\section{c. Pengajaran Berpikir Kritis}

Pembaca kritis tidak hanya memahami apa yang dibahas pada teks tetapi juga bagaimana penjelasan dari materi. Mereka mengenali variasi tiap teks dari penulis yang berbeda.

Pengajaran membaca kritis ialah mengarahkan siswa untuk menentukan dan menanyakan ide atau pikiran berdasarkan bukti nyata dengan menghubungkan pernyataan atau data logis. Prinsip pengajaran yang digunakan dalam penelitian ini mengikuti saran dari Reichenbach, (2001); Chaffee, 2000). Beberapa tahapan pengajaran juga mengikuti langkah yang diadopsi dari penelitian Emilia (2005) yang melakukan penelitian berpikir kritis pada membaca dan menulis.

Knot (2005) menyarankan bahwa siswa seharusnya mengenali aspek berikut dalam pengajaran berpikir kritis: 
1. Menentukan klaim utama atau tujuan teks. Membaca kritis menilai bagaimana klaim utama dikembangkan atau diperdebatkan.

2. Memulai membuat keputusan mengenai teks. Pembaca dari teks itu siapa? Siapa aja yang berdialog? Dalam konteks sejarah apa ditulis?

3. Menentukan tipe alasan yang digunakan pada teks. Konsep apa yang digunakan dan didefinisikan?apakah teks itu mengacu ke teori atau beberapa teori?apa metodologi yang digunakan? Jika itu mengacu pada konsep tertentu, teori atau metode, bagaimana konsep, teori atau metode digunakan untuk mengorganisasikan dan menginterpretasikan data? Mengevaluasi bukti (support dengan fakta, contoh dll) yang ada dalam teks.

4. Mendukung bukti merupakan hal yang penting pada argument. Mempertimbangkan bukti yang digunakan. Apa bukti yang digunakan pada argumen? apakah buktinya berupa statistik? literature? sejarah? dll, dari sumber apa bukti diambil? Apakah bukti ini sumber utama atau sumber kedua?

5. Membaca kritis bisa mencakup evaluasi. Membaca teks bisa dikatakan kritis bila bisa membuat keputusan bagaimana teks diperdebatkan. Jika argument kuat, kenapa? dapatkah itu menjadi lebih baik atau disupport berbeda? Apakah ada gap, tidak konsisten terhadap argumen?apakah metode analisis bermasalah? Dapatkah buktinya diinterpretasikan berbeda?apakah kesimpulan digaransi oleh bukti yang diberikan? Apakah asusmsi yang tidak dipaparkan? Apakah asusmsi tersebut bermasalah?apa argument yang berbeda?

Konsep berpikir kritis yang menjadi pijakan pembahasan dalam tulisan ini tidak terlepas dari konsep berpikir yang terjadi dalam aktifitas membaca. Berkaitan dengan hal ini, berpikir kritis diartikan sebagai kemampuan membuat keputusan rasional tentang apa yang dilakukan dan apa yang diyakini berkaitan dengan bacaan. Aktivitas berpikir kritis terjadi misalnya, ketika seseorang mengidentifikasi iklan yang menyesatkan, , mempertimbangkan bukti-bukti yang bertentangan, dan mengidentifikasi asumsi atau argumentasi yang keliru (Slavin, 1997 dalam Widuroyekti, 2006); mempertimbangkan dengan sungguh-sungguh dan hati-hati untuk memutuskan apakah menerima, menolak, atau menunda penilaian tentang suatu pernyataan (Moore dan Parker dalam Widuroyekti, 2006).

Berpikir kritis melibatkan sejumlah keterampilan. Moore dan Parker (1986) menyatakan "critical thingking involves a lot of skills, including the ability to listen and carefully, look for and find hidden assumptions and trace the consequences of claim'. Bahwa berpikir kritis meliputi banyak keterampilan, termasuk kemampuan menyimak dan membaca secara cermat, mencari dan menemukan asumsi-asumsi yang tersembunyi dan melacak konsekuensi suatu pernyataan.

Kemampuan berpikir kritis adalah kemampuan mengolah bahan bacaan untuk menemukan makna baik yang tersirat maupun yang tersurat melalui tahapan mengenal, memahami, menganalisis, mensintesis dan menilai. Mengolah bahan bacaan secara kritis artinya pembaca tidak hanya menagkap makna yang tersurat (reading on the lines), tetapi juga menemukan makna antarbaris (reading between the lines dan makna dibalik baris (reading beyong the lines ) (Beck dan Dole dalam Burns, 1996).

\section{MODEL PEMBELAJARAN PENINGKATAN KAPASISTAS BERPIKIR KRITIS DALAM MATA KULIAH MEMBACA}

Pembelajaran akan berlangsung efektif dan kritis apabila apabila guru terampil dalam mengajar. Metode yang dipergunakan oleh guru harus mengantarkan siswa agar mereka terampil dalam berpkiri kritis. Disamping itu siswa harus dirangsang agar berpikir mandiri dalam menghadapi sebuah dilemma, menyerap inti permasalahan, menentukan preposisi mengenai pengetahuan atau kemampuan kognitif. Guru sebagai model dalam membaca kritis dan berekspresi sangat berpengaruh terhadap keefektifan perilaku siswa di kelas. Pada akhirnya, siswa diharapkan mempunyai semangat yang besar untuk memberdayakan kemampuan berpikirnya sehingga menjadi sebuah sikap positif yang melekat pada diri siswa (Patrick, 2003 dalam Hoerudin, 2010).

Untuk merumuskan sebuah formula pembelajaran yang dapat memberdayakan dan meningkatkan ketrampilan berpikir kritis siswa, guru harus memahami prinsip-prinsip peningkatan ketrampilan berpikir kritis. Berikut ini prinsipprinsip peningkatan menurut Chiras (1992:464 dalam Hoerudin, 2010).

1. Mengumpulkan informasi yang lengkap.

2. memahami dan mendefinikan istilah yang-istilah yang ada.

3. Menanyakan teknik-teknik dari fakta-fakta yang diperoleh.

4. Menanyakan kesimpulan

5. Mencari asumsi-asumsi dari pandangan yang tersembunyi

6. Menganalisa jawaban

7. Memeriksa gambar besar

8. Memeriksa sebab-sebab dan atribut-atribut yang kompleks

9. Hati-hati terhadap hal-hal yang bisa dipilih 
10. Memahami prosedur-prosedur dan pemikiranpemikiran sendiri.

Prinsip-prinsip tersebut merupakan bentuk kegiatan berpikir kritis yang perlu dikolaborasikan dengan kegiatan lain, misalnya diskusi, tanya jawab, dan inquiri. Kegiatan-kegiatan tersebut sangat padu, sebab menuntut aktivitas yang sangat tinggi dalam berpikir.

\section{TAHAPAN MODEL}

Model mengajar yang dikembangkan Piaget terdiri atas tiga tahapan:

1. Tahapan pertama: konfrontasi

Pada tahapan ini murid dihadapkan pada situasi yang menantang, penuh teka-teki dan kadangkadang bersifat logis. Murid diharapkan beradaptasi terhadap situasi tersebut sehingga pemikirannya mekar dan dapat memecahkan teka-teki itu. Akan tetapi guru harus menciptakan situasi yang sebaik mungkin dan terutama memberikan masalah yang sesuai dengan tingkat perkembangan murid.

2. Tahap kedua: Inquiri

Pada tahapan ini guru mengusahakan agar respon murid digali dan muncullah tingkat berpikir tertentu dan dinilai oleh guru. Teknik yang digunakan adalah probing dengan cara:

a. bertanya untuk meyakinkan sesuatu

b. melakukan counter suggestion misalnya dengan menanyakan "apakah yang anda pikirkan?" "apakah yangh anda lihat?"

c. menemukan respon murid yang tepat

d. menanyakan murid tentang alasan-alasan pembenaran responnya, misalnya dengan menanya "Bagaimana anda tahu?"

3. Tahapan Ketiga: Transfer

Pada tahapan ini guru mengemukakan suatu masalah baru yang menantang murid untuk berpikir. Jika murid telah mencoba memecahkan masalah itu, guru melakukan counter suggestion dengan menanyakan alas an-alasan dan menggali pemikirannya lebih jauh tentang masalah tersebut. Tujuan tahapan ini agar murid dapat mentransfer kemampuan berpikirnya terhadap berbagai masalah.

\section{SIMPULAN}

Model pembelajaran meningkatkan kapasitas berpikir kritis dilandasi oleh teori kognitif dan asusmsi bahwa membaca merupakan suatu proses dalam memahami pikiran penulis yang dituangkan dalam bacaan. Untuk dapat memahami sebuah teks, pembaca harus memberdayakan kapasistas berpikirnya dengan optimal. Karena membaca adalah suatu proses maka dalam pembelajarannya tidak hanya dikoreksi hasil belajarnya saja tetapi diperhatikan pula tingkat perkembangan ketrampilannya.

\section{DAFTAR PUSTAKA}

Alaqozlu, N. (2006). Some Discourse-Based Suggestions that Boost Critical Thinking Skills in ELT Classes. Retrieved 12 July, 2009 from http: dergiler.ankara.edu.tr/dergiler/27/758/9642 .pdf

Beyer, Barry K. (1997). Improving Student Thinking: A Comprehensive Approach. Boston: Allyn and Bacon

Buranapatana, M. (2006). Enhancing Critical Thinking of undergraduate Thai Students through Dialogic Inquiry. A Thesis. Unpublished.

Cresswell, J. W. (2008). Educational Research. New Jersey: Pearson Education, Inc

Diestler, H. (2001). Becoming A Critical Thinker: A User Friendly Manual. Jersey: Prentice Hall, Inc.

Ennis, H.R. (1996). Critical Thinking USA: Prentice Hall

Ennis, H.R. (2003). “Critical Thinking Assessment'. In Fasco, Jr. D. (2003). (Ed). Critical Thinking and Reasoning. Current Research, Theory, and Practice. Cresskill, New Jersey: Hampton Press.Inc.

Emilia, E. (2005). A critical Genre Based Approach to Teaching Academic Writing in A Tertiary Level Context in Indonesia. Unpublished

Facrhrurazi. 2011. Penerapan Pembelajaran berbasis masalah untuk meningkatkan kemampuan berpikir kritis dan komunikasi Matematis siswa sekolah dasar. Edisi Khusus No 1 agustus 2011.

Freire, A.M.A., and Macedo, D. (1998). The Paulo Freire Reader. New York: The Continuum Publishing Company

Hoerudin ,Cecep Wahyu. 2010. Pengembangan membaca Kritis melalui penerapan model pembelajaran peningkatan kapasitas berpikir kritis. Jurnal Bahasa dan sastra Vol 1 No 2 Oktober 2010.

Kabilan, M. K. (2000). Creative and critical thinking in language classrooms. The Internet TESL Journal, 6(6). Retrieved 
July 1st, 2010 from Paul, R. W. (1995). Critical Thinking: How to http://itselj.org/Techniques/Kabilian- $\quad$ Prepare Students for a Rapidly Changing Critical Thinking. html

Knott, D. (2008). Critical Reading toward Critical Writing. New College Writing Centre http://www.utoronto.ca/writing/ critrdg.html

Kustini, (2010). Enhancing students critical thingking. Unpublished thesis UPI.

Ling Liaw, M. (2007). Content Based Reading and Writing for Critical Thinking Skills in an EFL Context.

Lipman, M. (2003). Thinking in Education. Second Edition, Cambridge:

Cambridge University Press.

McPeck, John E. (1990). Teaching Critical Thinking. London: Routledge

Moore, Brooke N. \& Parker, R. (1994). Critical Thinking. London:

Mayfield Publishing Company World. Santa Rosa: Foundation for Critical Thinking

Reichenbach, B. H. (2001). Introduction to Critical Thinking. New York: McGraw-Hill.

Widuroyekti, B. 2006. Pengembangan kemampuan berpikir melalui pembelajaran membaca kritis di sekolah dasar kelas tinggi. Pusat studi Indonesia lembaga penelitian UT.

Volume 6, No. 5, September 2012 